VOL. 6

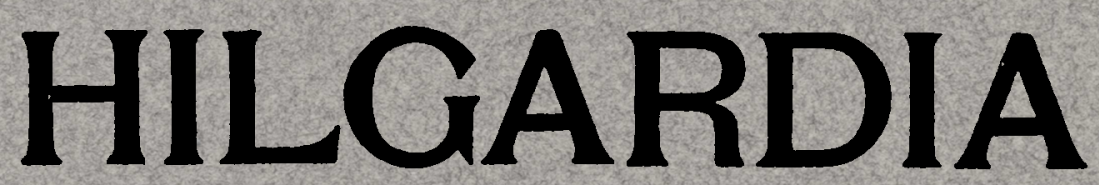

A Journal of Agricultural Science

PUBLISHED BY THB

California Agricultural Experiment Station

\title{
CONTENTS
}

Modes of Curly-Top Transmission by the Beet Leafhopper, Eutettix tenellus (Baker)

HENRY H. P. SEVERIN 
The tities of the Technical Papers of the Oalifornta Agricultural Experiment Station, N08. 1 to 20, which HIILGARDIA replaces, and coples of which mas be had on application to the Publication Secretary, Agricuitural Inperiment station, Berkeley, are as follows:

4. Effect of sodinm Chlorid snd Calcium Chlorld upon the Growth and Com position of Young Orange Trees, by H. 8. Reed and A. B. O. Hane. Aprll, 1923.

5. Oitrus Blast and Black Pit, by H. 8. Fawcett, W. T. Horne, and A. F. Camp. May, 1923.

6. A Study of Dociduous Fruit Troo Rootstocks with Special Reference to Their Identiflcation, by Myer J. Heppner. June, 1923.

7. A study of the Darkening of Apple Tissue, by Z. I. Overholser and W. V. Cruess. June, 1923.

8. Effect of 8alts on the Intake of Inorganic Elements and on the Buffer System of the Plant, by D. R. Hargland and J. O. Neartin. July, 192s.

9. Experiments on the Reclamation of Alkall Bofls by Leaching with Water and Gypsum, by P. I. Hubbard. Angust, 1928.

10. The Beasonal Variation of the Boll Molsture in a Walnut Grove in Belation to Hygroscopic Coefiletent, by L. D. Batchelor and E. 8. Boed. Bepteme ber, 1923.

11. Studies on the Effects of Sodium, Potassdum, and Oulcium on Young Orange Troek, by II. 8. Roed and A. B. O. Haas October, 182s.

12. The Fffect of the Plant on the Reaction of the Oultare Bolution, by D. $\mathbf{Z}$. Foagland. Norember, 1923.

14. The Rospiration of Potato Tubers in Relation to the Occurrence of Blactheart, by J. P. Bennett and E. T. Bartholomew. January, 1924.

16. The Molsture Equivalent as Influenced by the Amount of Boll Used in its Determination, by F. J. Volhmeyer, O. W. Israelsen and J. P. Conrad. September, 1924.

17. Nutrient and Toxic Effects of Certain Ions on Citrus and Walnut Treos with Especial Reference to the Concentration and $\mathrm{Ph}$ of the Madium, by II. 8. Beed and A. I . O. Haas. October, 1924.

18. Factors Infuencing the Rate of Cermination of Beed of Arparagus Omalnalis, by H. A. Borthwick March, 1925.

19. The Relation of the 8ubcutaneous Administration of Ifving Bacteritum abortum to the Immunity and Carrier Problem of Bopine Infectlous Abortion, by Georgo H. Hart and Jacob Traum. Aprll, 1925.

20. A Study of the Conductive Tisones in Bhoots of the Bartiett Pear and the Relationship of Food Movement to Dominance of the Apical Buds b/ Frank I. Gardner. April, 1925. 


\title{
HILGARDIA
}

\author{
A JOURNAL OF AGRICULTURAL SCIENCE \\ PUBLISHED BY THE
}

CALIFORNIA AGRICULTURAL EXPERIMENT STATION

VoL. 6

NOVEMBER, 1931

No. 8

\section{MODES OF CURLY-TOP TRANSMISSION BY THE BEET LEAFHOPPER, EUTETTIX TENELLUS (BAKER)}

HENRY H. P. SEVERIN1

(Contribution from the Division of Entomology and Parasitology, California Agricultural Experiment Station, University of California, cooperating with the United States Department of Agriculture, Bureau of Entomology.)

\section{INTRODUCTION}

A number of scientists have worked on the incubation period of the curly-top virus in the beet leafhopper, Eutettix tenellus (Baker), in which the infective principle passes into the mouth parts, alimentary canal, blood, salivary glands and out of the mouth parts in sufficient quantity to produce infection. It has been known for a long time that previously noninfective beet leafhoppers are able to transmit curly top in short periods after feeding on diseased beets. A number of theories have been published recently attempting to explain these short periods of curly-top transmission. A short review of the literature on this subject is given in the following paragraphs.

Smith and Boncquet ${ }^{(13)}$ state that not more than 3 hours of feeding were necessary to obtain the pathogenic factor, but that a period of at least 24 hours and not more than 48 hours must elapse before the insect could transmit the disease. These facts suggested to them that curly top was not transferred mechanically, but that some development or change took place within the body of the insect during the first few hours after feeding on a diseased plant.

\footnotetext{
1 Associate Entomologist in Experiment Station.
} 
Severin ${ }^{(7)}$ found that adults previously noninfective were occasionally able to transmit curly top within 4,5 , or 6 hours after feeding on a diseased beet under high temperatures (mean $100.0^{\circ}$ to $115.6^{\circ}$ F). Eight cases (13.3 per cent) of curly top developed from 60 beets used in this experiment. Lots of 25 or 50 males were used instead of single leafhoppers. Curly top was not produced by beet leafhoppers with hourly trials of from 1 to 10 hours under lower temperatures (maximum $80^{\circ}-86^{\circ} \mathrm{F}$ ) in the greenhouse during October and November.

Severin $^{(9)}$ also reported that 100 lots of 25 or 50 adults failed to transmit the infective principle of curly top to 114 beets within 1, 2, or 3 hours. In two experiments, 9 lots of from 100 to 1,000 nymphs or adults failed to communicate the virus to 27 beets within 2,3 , and 4 hours. Beet leafhoppers previously noninfective transmitted curly top to 15 of 126 beets (11.9 per cent) within 4, 5, 6, and 10 hours. He found later ${ }^{(11)}$ that leafhoppers previously noninfective transmitted curly top within 2 hours after feeding on a diseased beet.

Later experiments included in this paper showed shorter periods of curly-top transmission by the beet leafhoppers.

Swezy ${ }^{(14)}$ found two large masses of bacteria in the lumen of the esophagus anterior to the esophageal valve (fig. 1) in a single beet leafhopper of 250 specimens examined. Similar masses of bacteria were found in the midintestine of other specimens, but the esophageal valve was not clogged. She assumed that the two masses of bacteria anterior to the valve might hinder the free passage of food into the midintestine and that it might be possible for the infected beet juice to be regurgitated from the esophagus through the mouth parts. She concluded that "if, as seems very probable, this is the case, this condition would explain the occurrence of infection in $1 / 2$ or 1 hour." (14)

Bacot and Martin (1) found that two species of rat fleas, Xenopsylla cheopis and Ceratophyllus f(ssiatus, can transmit Bacillus pestis, the cause of bubonic plague, through regurgitation from the foreintestine. When the alimentary canals of fleas showing successive stages of development of the bacilli are examined (fig. 2), it is evident that the proventricular valve is clogged with bacteria and extends into the esophagus and stomach. When fleas in this condition feed, the contaminated esophagus becomes distended with blood, and when the pharynx ceases to pump, some of the blood is regurgitated from the esophagus and is forced out of the mouth parts. Such fleas are persistent in their endeavor to feed, and this renders them particularly dangerous. 
Swezy ${ }^{(14)}$ fed beet leafhoppers on stains dissolved in a sugar solution and found that the cells of the midintestine were stained in $\mathbf{1 5}$ minutes and the salivary glands at the end of 1 hour under high temperatures. It was assumed from this experiment that an infective organism might remain unchanged in its passage through the midintestine, blood, and salivary glands and when injected with the saliva into a healthy beet seedling might occasionally produce infection at short intervals.

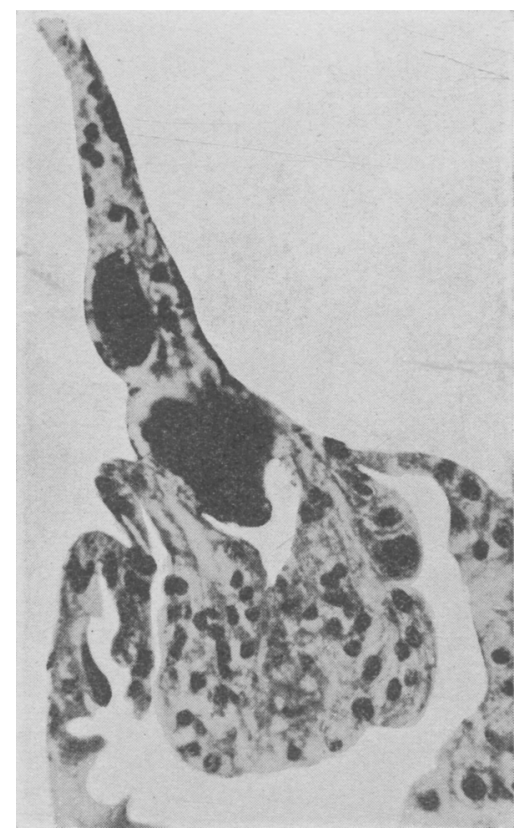

Fig. 1. Photomicrograph of esophageal valve with two masses of bacteria lodged in the esophagus anterior to it. (After Swezy.)

Another theory suggested by Swezy(14) is as follows: "An alternative explanation is found in the fact that a change in the life cycle of the infective organism occurs in the body of the insect and this must be completed before the insect is capable of readily transmitting the disease to a healthy plant. This explanation is not incompatible with the finding of an occasional transmission of curly top within such intervals as 1 or 2 hours."

In this paper further experiments are reported on short periods required for previously noninfective insects to transmit curly top to healthy beets after feeding on diseased beets. Investigations were also undertaken on the transmission of curly top by single beet leaf- 


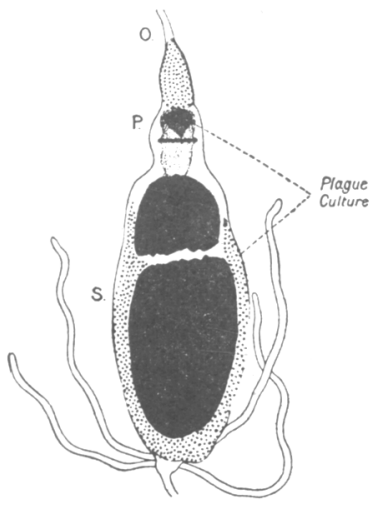

$a$
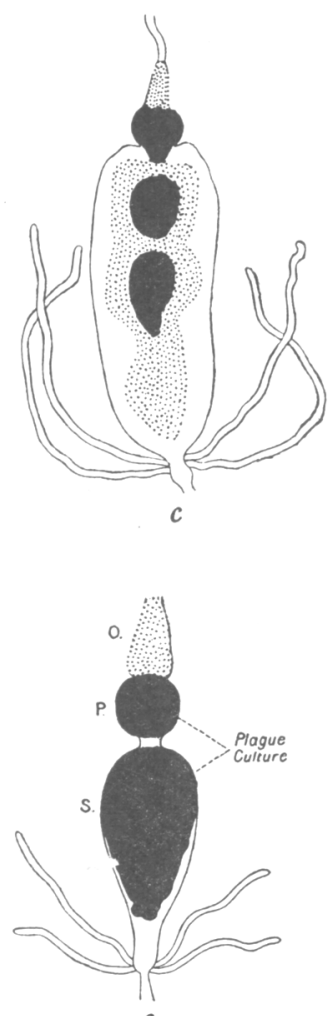

e
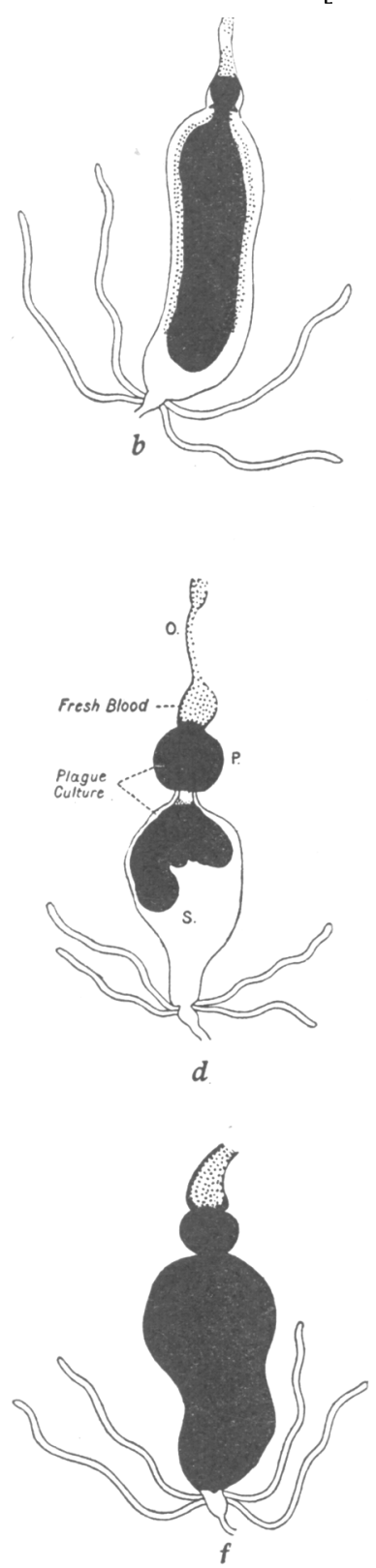

Fig. 2. Alimentary canals of fleas showing successive stages of development of Bacillus pestis, the cause of bubonic plague. The bacilli grow so abundantly as to clog the proventriculus. Fleas in this condition are not prevented from sucking blood, but when the pharynx ceases to pump, regurgitation of the contaminated blood occurs through the esophagus and some of the blood is forced out of the mouth parts. Plague cultures are shown black; fresh blood, stippled. $O$, esophagus; $P$, proventriculus; $S$, stomach. (Adapted from Bacot and Martin.) 
hoppers in longer periods, the relation of mass inoculation by groups of insects to curly-top transmission, and the virus incubation period in the insect. Experiments were conducted on curly-top transmission by contamination of mouth parts. Inoculation experiments were also undertaken with the feces of infective beet leafhoppers.

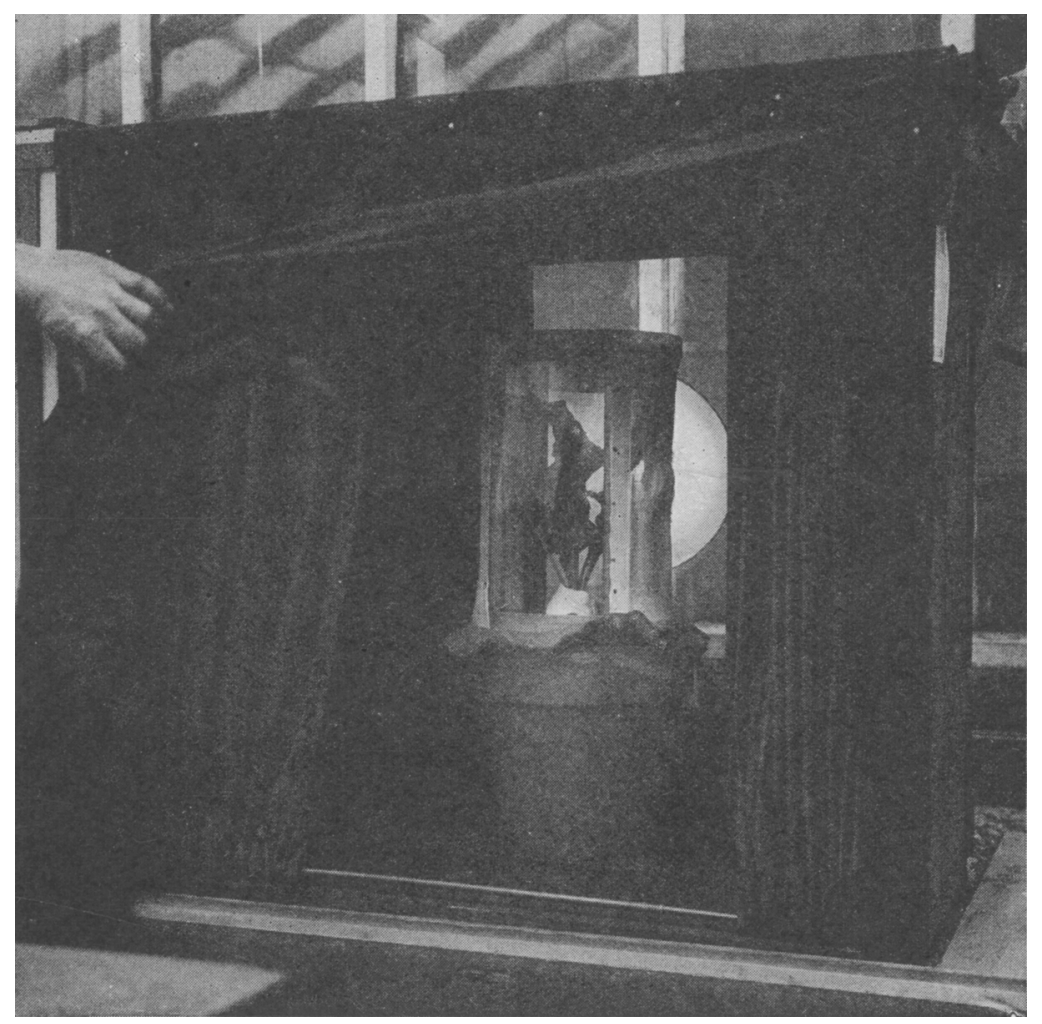

Fig. 3. Dark chamber in which transfers of beet leafhoppers were made to prevent escape of adults. If a leafhopper escaped, it was attracted to the light of an electric lamp enclosed in a reflector outside of the glass plate.

\section{METHODS}

The methods used in the transmission of curly top by the beet leafhopper varied in different experiments. Beet leafhoppers were either fasted overnight or during the morning in a cool room in many experiments. The insects, within cages, were fed on curly-top beets from which the outer leaves not showing symptoms of the disease had been removed. The hoppers were transferred to healthy beet seedlings 
with from 6 to 12 leaves. The removal of the cages from the beets was performed in a dark chamber provided with a glass plate, outside of which was a 50-watt electric lamp covered with a shade (fig. 3), so that any adults that remained on the plant, resting between the petioles, were attracted to the light after the cage was removed. Precautions were taken that all of the insects were removed from the plants in the transfers. The inoculated beets were fumigated with Nico-Fume tobacco-paper insecticide and were kept within insectproof cages for a period of 3 months if symptoms did not develop within the usual period of 1 to 2 weeks.

\section{SHORT PERIODS OF CURLY-TOP TRANSMISSION BY BEET LEAFHOPPERS}

In determining the short periods of curly-top transmission by the beet leafhopper, high temperatures were usually used, so that the insects would feed during the short periods on the diseased and healthy beets. In most experiments the hoppers were transferred to successive healthy beet seedlings. After the last transfer of the insects the hoppers were counted. The length of time that the leafhoppers were left on diseased and healthy beets is given in table 1 . The number of leafhoppers used is given only when infection was produced.

It is evident from table 1 that curly top was transmitted to a healthy beet seedling within $1 / 3,1 / 2,1,1 \frac{1}{2}, 2,3$, and 4 hours. Table 1 shows that the percentage of curly-top transmission varied from 2.4 per cent within $1 / 3$ hour to 33.3 per cent within 4 hours.

It is evident from table 1, that each lot of 178 and 350 hoppers caused infection in 3 successive beets. On the other hand, a lot of 1,000 insects transmitted the infective principle within 2 and 4 hours, but failed in the 3-hour test. A lot of 1,153 leafhoppers transmitted curly top within 2 and 3 hours but failed in 4 hours.

When 20 to 50 adults were used, the transmission of curly top within $1 / 3,1 / 2,1,1 \frac{1}{2}, 2,3$, and 4 hours averaged 7.3 per cent with 96 beets, as compared with 22.5 per cent with 129 beets when more than 50 hoppers were used. No infections were obtained when 5 to 15 insects were used.

Trials conducted in late summer or in the autumn were not as successful as during the months of May, June, and July, in which high temperatures can often be obtained in the fog belt at Berkeley. 
TABLE 1

Short Periods of Curly-Top Transmission by Beet Leafhoppers

\begin{tabular}{|c|c|c|c|c|c|c|c|c|c|}
\hline \multirow{2}{*}{$\begin{array}{c}\text { Total } \\
\text { period on } \\
\text { curly-top } \\
\text { and healthy } \\
\text { beets, } \\
\text { hours }\end{array}$} & \multicolumn{2}{|c|}{$\begin{array}{c}\text { Length of time, } \\
\text { hours }\end{array}$} & \multirow{2}{*}{$\begin{array}{c}\text { Number } \\
\text { of } \\
\text { beets } \\
\text { infected }\end{array}$} & \multirow{2}{*}{$\begin{array}{c}\text { Number } \\
\text { of } \\
\text { beets } \\
\text { inoculated }\end{array}$} & \multirow{2}{*}{$\begin{array}{l}\text { Per cent } \\
\text { infected }\end{array}$} & \multirow{2}{*}{$\begin{array}{l}\text { Number of } \\
\text { leafhoppers } \\
\text { used on } \\
\text { beets that } \\
\text { developed } \\
\text { curly top }\end{array}$} & \multicolumn{3}{|c|}{$\begin{array}{c}\text { Temperatures } \\
\text { during feeding period } \\
\text { of leafhoppers, } \\
\text { degrees } F\end{array}$} \\
\hline & $\begin{array}{l}\text { curly- } \\
\text { top } \\
\text { beet }\end{array}$ & $\begin{array}{c}\text { healthy } \\
\text { beet }\end{array}$ & & & & & $\begin{array}{l}\text { Maxi- } \\
\text { mum }\end{array}$ & $\begin{array}{l}\text { Mini- } \\
\text { mum }\end{array}$ & Mean \\
\hline $1 / 3$ & $1 / 6$ & 1,6 & 1 & 41 & 2.4 & 40 & 110 & 102 & 106.0 \\
\hline $\begin{array}{l}1 / 2 \\
1 / 2\end{array}$ & $\begin{array}{l}1 / 4 \\
1 / 4\end{array}$ & $\begin{array}{l}1 / 4 \\
1 / 4\end{array}$ & $\begin{array}{l}1 \\
1\end{array}$ & 14 & 14.3 & $\begin{array}{r}40 \\
300\end{array}$ & $\begin{array}{l}109 \\
110\end{array}$ & $\begin{array}{l}104 \\
105\end{array}$ & $\begin{array}{l}106.5 \\
107.5\end{array}$ \\
\hline 1 & $1 / 2$ & $1 / 2$ & 1 & 34 & 2.9 & 50 & 110 & 104 & 107.0 \\
\hline $11 / 2$ & 1 & $1 / 2$ & 1 & & & 20 & 96 & 94 & 95.0 \\
\hline $11 / 2$ & $1 / 2$ & 1 & 1 & 24 & 16.7 & 40 & 96 & 94 & 95.0 \\
\hline $11 / 2$ & $1 / 2$ & 1 & 1 & & & 95 & 125 & 114 & 119.5 \\
\hline $11 / 2$ & $1 / 2$ & 1 & 1 & & & 127 & 112 & 102 & 107.0 \\
\hline 2 & $1 / 2$ & $11 / 2$ & 1 & & & 34 & 129 & 114 & 121.5 \\
\hline 2 & 1 & $1^{*}$ & 1 & & & 178 & 116 & 102 & 109.0 \\
\hline 2 & 1 & $1^{*}$ & 1 & 40 & 15.0 & 350 & 116 & 102 & 109.0 \\
\hline 2 & 1 & $1^{*}$ & 1 & & & 1,000 & 116 & 102 & 109.0 \\
\hline 2 & 1 & $1^{*}$ & 1 & & & 1,071 & 116 & 102 & 109.0 \\
\hline 2 & 1 & $1^{*}$ & 1 & & & 1,153 & 129 & 114 & 121.5 \\
\hline 3 & $1 / 2$ & 1 & 1 & & & $2 j$ & 132 & 114 & 123.0 \\
\hline 3 & 1 & $1^{*}$ & 1 & & & 178 & 116 & 102 & 109.0 \\
\hline 3 & 1 & $1^{*}$ & 1 & & & 332 & 116 & 102 & 109.0 \\
\hline 3 & 1 & $1^{*}$ & 1 & & & 350 & 116 & 102 & 109.0 \\
\hline 3 & 1 & $1^{*}$ & 1 & 36 & 27.8 & 455 & 116 & 102 & 109.0 \\
\hline 3 & $1 / 2$ & 1 & 1 & & & 515 & 118 & 102 & 110.0 \\
\hline 3 & 1 & $1^{*}$ & 1 & & & 578 & 116 & 102 & 109.0 \\
\hline 3 & 1 & $1^{*}$ & 1 & & & 864 & 116 & 102 & 109.0 \\
\hline 3 & 1 & $1^{*}$ & 1 & & & 1,071 & 116 & 102 & 109.0 \\
\hline 3 & 1 & $1^{*}$ & 1 & & & 1,153 & 116 & 102 & 109.0 \\
\hline 4 & $1 / 2$ & 1 & 1 & & & 80 & 133 & 114 & 123.5 \\
\hline 4 & $1 / 2$ & 1 & 1 & & & 95 & 133 & 114 & 123.5 \\
\hline 4 & $1 / 2$ & 1 & 1 & & & .127 & 120 & 102 & 111.0 \\
\hline 4 & 1 & $1^{*}$ & 1 & & & 178 & 116 & 102 & 109.0 \\
\hline 4 & $1 / 2$ & 1 & 1 & & & 229 & 120 & 102 & 111.0 \\
\hline 4 & 1 & $1^{*}$ & 1 & 36 & 33.3 & 291 & 113 & 106 & 109.5 \\
\hline 4 & 1 & $1^{*}$ & 1 & & & 332 & 116 & 102 & 109.0 \\
\hline 4 & 1 & $1^{*}$ & 1 & & & 350 & 116 & 102 & 109.0 \\
\hline 4 & 1 & $1^{*}$ & 1 & & & 448 & 116 & 102 & 109.0 \\
\hline 4 & 1 & $1^{*}$ & 1 & & & 864 & 116 & 102 & 109.0 \\
\hline 4 & 1 & $1^{*}$ & 1 & & & 1,000 & 116 & 102 & 109.0 \\
\hline 4 & 1 & $1^{*}$ & 1 & ) & & 1.071 & 116 & 102 & 109.0 \\
\hline
\end{tabular}

* Fed 1 hour each on successive healthy beets.

Curly top was not transmitted to any of 42 beets within 2, 3, or 4 hours after the hoppers had fed on diseased beets on August 21 and September 6. The number of hoppers varied from 133 to 405 on each beet, a total of 3,759 being used in two experiments. The insects were 
fed for a period of 1 hour on the diseased beets and were then transferred to successive healthy beets. At the end of each test each lot of leafhoppers was kept on a healthy beet for 2 weeks to determine whether they became infective in feeding for a period of 1 hour on a diseased beet. Fourteen lots of hoppers used in the two experiments transmitted curly top to 14 beets.

It has frequently been observed that recently molted adults, after the chitin has hardened, feed for several hours. It was, therefore, decided to test these insects for short periods of transmission of the virus. Twenty previously noninfective male leafhoppers after passing through the last molt were kept in a cage without food for a period of 3 to 4 hours, and then each specimen was fed on a different diseased beet for an hour. Each insect was disturbed in its meal and fed on a separate healthy beet for another hour, but not a single case of curly top developed.

\section{TRANSMISSION OF CURLY TOP BY SINGLE BEET LEAFHOPPERS}

Experiments conducted up to the present time using one insect in each test seem to demonstrate that a single beet leafhopper does not transmit curly top in short periols. As stated in a previous paper ${ }^{(7)}$ 44 previously noninfective nymphs were fed singly upon diseased leaves for a period of 1 to 2 minutes, and each nymph was then fed on a healthy beet for 5 minutes, or less, if it completed its meal befcre the end of that time, but not a single case of curly top developed. It was demonstrated, however, that 21 previously noninfective nymphs fed from 1 to 2 minutes on a diseased beet, and then fed on a healthy beet for a period of two weeks, transmitted curly top.

In a later experiment 20 nymphs were fed singly upon diseased beets for a period of 1 to 4 minutes and then each hopper was fed on a healthy beet from 3 to 22 minutes until it completed its meal. In another experiment 14 nymphs and 6 adults were fed singly upon curly-top beets for 10 minutes and then each hopper was disturbed in its meal and transferred to a healthy beet seedling for 10 minutes. Negative results were obtained with all of the 40 beets.

In the next experiment previously noninfcctive beet leafhoppers were fed singly on diseased and healthy beet seedlings for periods varying from 2 to 11 hours under high temperatures, as indicated in table 2. Each leafhopper was fed on a diseased beet seedling showing either the early symptom of the disease, namely, the transparent 
venation, or the wart-like protuberances on the lower surface of the leaves. The outer leaves without symptoms were removed from each beet. A similar experiment was also undertaken with infective male beet leafhoppers which had completed the nymphal stages on a diseased beet. Each male was left on a healthy beet seedling for periods varying from 1 to 11 hours. The results are shown in table 2 .

TABLE 2

Transmission of Curly-Top Virus by Single BeEt Leafhoppers

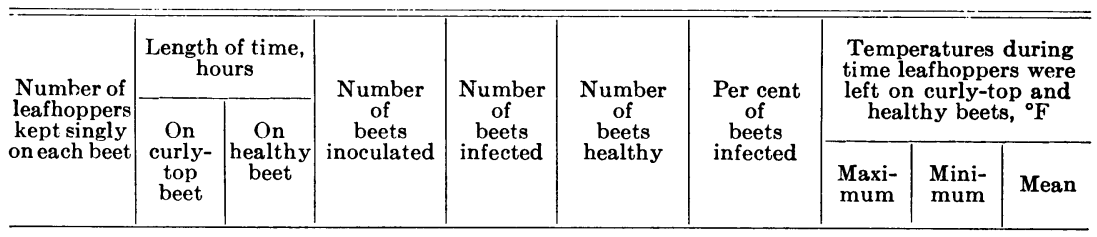

Previously noninfective leafhoppers

\begin{tabular}{|c|c|c|c|c|c|c|c|c|c|}
\hline 10 & 1 & 1 & 10 & 0 & 10 & 0 & 116 & 110 & 113.0 \\
\hline 10 & 1 & 2 & 10 & 0 & 10 & 0 & 100 & 92 & 96.0 \\
\hline 15 & 2 & 1 & 15 & 0 & 15 & 0 & 107 & 100 & 103.5 \\
\hline 10 & 2 & 2 & 10 & 0 & 10 & 0 & 100 & 82 & 91.0 \\
\hline 15 & 3 & 1 & 15 & 0 & 15 & 0 & 116 & 92 & 104.0 \\
\hline 10 & 4 & 1 & 10 & 0 & 10 & 0 & 102 & 92 & 97.0 \\
\hline 13 & 3 & 3 & 13 & 0 & 13 & 0 & 100 & 92 & 96.0 \\
\hline 15 & 5 & 1 & 15 & 0 & 15 & 0 & 92 & 82 & 87.0 \\
\hline 15 & 6 & 1 & 15 & 1 & 14 & 6.7 & 100 & 88 & 94.0 \\
\hline 10 & 4 & 4 & 10 & 0 & 10 & 0 & 100. & 82 & 91.0 \\
\hline 14 & 7 & 1 & 14 & 0 & 14 & 0 & 98 & 71 & 84.5 \\
\hline 16 & 8. & 1 & 16 & 1 & 15 & 6.2 & 102 & 82 & 92.0 \\
\hline 14 & 9 & 1 & 14 & 0 & 14 & 0 & 100 & 80 & 90.0 \\
\hline 16 & 5 & 5 & 16 & 1 & 15 & 6.2 & 102 & 82 & 92.0 \\
\hline 10 & 3 & 8 & 10 & 1 & 9 & 10.0 & 100 & 82 & 91.0 \\
\hline 10 & 10 & 1 & 10 & 0 & 10 & 0 & 100 & 80 & 90.0 \\
\hline Total & $\ldots \ldots .$. & ......... & 203 & 4 & 199 & 2.0 & ......... & $\ldots \ldots$ & .......... \\
\hline \multicolumn{10}{|c|}{ Infective leafhoppers } \\
\hline 20 & & 1 & 20 & 5 & 15 & 25.0 & 104 & 95 & 99.5 \\
\hline 20 & & 2 & 20 & 2 & 18 & 10.0 & 104 & 98 & 101.0 \\
\hline 12 & & 3 & 12 & 3 & 9 & 25.0 & 92 & 90 & 91.0 \\
\hline 12 & Rear- & 4 & 12 & 6 & 6 & 50.0 & 92 & 90 & 91.0 \\
\hline 17 & ed on & 5 & 17 & 8 & 9 & 47.1 & 94 & 88 & 91.0 \\
\hline 17 & curly- & 6 & 17 & 10 & 7 & 58.8 & 92 & 82 & 87.0 \\
\hline 15 & $\begin{array}{c}\text { curiy- } \\
\text { top }\end{array}$ & 7 & 15 & 5 & 10 & 33.3 & 96 & 84 & 90.0 \\
\hline 16 & $\begin{array}{c}\text { top } \\
\text { beets }\end{array}$ & 8 & 16 & 10 & 6 & 62.5 & 88 & 76 & 82.0 \\
\hline 16 & & 9 & 16 & 11 & 5 & 68.7 & 94 & 76 & 85.0 \\
\hline 7 & & 10 & 7 & 5 & 2 & 71.4 & 106 & 74 & 90.0 \\
\hline 17 & & 11 & 17 & 7 & 10 & 41.2 & 94 & 72 & 88.0 \\
\hline Total & $\ldots \ldots .$. & $\ldots \ldots .$. & 169 & 12 & 97 & 42.6 & $\ldots \ldots . .$. & .......... & .......... \\
\hline
\end{tabular}


According to table 2, only 4 of a total of 203 beets deve'oned top after being exposed to single previously noninfective beet leafhoppers that had fed on diseased and then on the healthy beet seedlings for periods varying from 2 to 11 hours. The shortest period required for a single leafhopper to transmit curly top was 7 hours. The length of time that each leafhopper transmitting the disease was confined on diseased beets was $6,8,5$, and 3 hours and on healthy beets $1,1,5$, and 8 hours, respectively.

TABLE 3

Transmission of Curly Top by Single Beet Leafhoppers Which Were Kept for Varying Periods on Diseased Beets and Then Transferred Hourly to Successive Healthy Beets

\begin{tabular}{c|c|c|c|c|c|c}
\hline $\begin{array}{c}\text { Number of } \\
\text { single leafhoppers } \\
\text { kept on } \\
\text { healthy beets }\end{array}$ & $\begin{array}{c}\text { Length } \\
\text { of time on } \\
\text { curly-top } \\
\text { beets, } \\
\text { hours }\end{array}$ & $\begin{array}{c}\text { Virus } \\
\text { incubation period } \\
\text { in leafhoppers } \\
\text { in hourly } \\
\text { tests }\end{array}$ & $\begin{array}{c}\text { Virus } \\
\text { incubation periods } \\
\text { in leafhoppers } \\
\text { producing infec- } \\
\text { tions, hours }\end{array}$ & $\begin{array}{c}\text { Number } \\
\text { of } \\
\text { beets } \\
\text { inoculated }\end{array}$ & \multicolumn{2}{|c}{ Beets infected } \\
\hline 20 & 4 & $16-23$ & $17,21,22,22,23,23$ & 160 & 5 & 3.1 \\
10 & 12 & $13-20$ & 14,20 & 80 & 2 & 2.5 \\
10 & 20 & $20-23$ & 21 & 40 & 2 & 5.0 \\
10 & 21 & $22-23$ & 0 & 20 & 0 & 0.0 \\
\hline 50 & $\ldots$ & $13-23$ & $\ldots \ldots \ldots \ldots \ldots \ldots .$. & 300 & 9 & 3.0 \\
\hline
\end{tabular}

The transmission of curly top by single infective beet leafhoppers left on healthy beet seedlings for periods of 1 to 3 hours varied from 10.0 to 25.0 per cent, as compared with 33.3 to 71.4 per cent for periods of 4 to 11 hours. The percentage of infection did not constantly vary directly as the time of exposure on healthy beets. Repeated inoculations of the beet seedlings during the longer feeding periods probably increases the amount of virus injected into the beet and explains the higher percentage of infection obtained.

A number of experiments were undertaken varying the exposure of previously noninfective beet leafhoppers on diseased beets and then transferring each insect hourly to successive healthy beets. The hoppers were fasted from 2 to 7 hours in empty cages and were then exposed to diseased beets for periods varying from 4 to 21 hours as indicated in table 3 . In the first experiment indicated in table 3, 20 previously noninfective males were fasted for 2 hours, left on a diseased beet for 4 hours, and fasted for 12 hours to avoid transmission of the disease by contamination of mouth parts. It is not known how long the virus remains viable on the mouth parts, but it was assumed that it would not be viable after the insects had been kept in cages without food for 12 hours. In the next three experiments the insects 
in cages remained on diseased beets overnight, and the glass of the cage was placed in front of 2 e'ectric lamps provided with reflectors. The transmission of curly top by single insects with a virus incubation period of 13 to 23 hours is shown in table 3 .

According to table 3, 50 leafhoppers with an incubation period of 13 to 23 hours transmitted curly top to 9 (3 per cent) of 300 beets. Table 2 shows that 203 beet leafhoppers tested singly, with an incubation period of 2 to 11 hours, transmitted curly top to 4 ( 2 per cent) of 203 beets. The first set of data were obtained with leafhoppers which fed on diseased beets at night, whereas the second set of data were obtained with insects which were fed on diseased and healthy beets during the daytime and at higher temperatures.

\section{MASS INOCULATION}

Carsner and Lackey ${ }^{(3)}$ state that the relation of mass action to curly-top infection has been shown by the following methods: “(1) By varying the amount of inoculated virus by $(a)$ inoculations with contrasting numbers of leafhoppers and $(b)$ unequal periods of exposure; (2) by use of plants differing in susceptibility; (3) by studies on the incubation of the virus in the insect; and (4) by comparing the minimal infective doses of the virus in its virulent and attenuated conditions." However, no experimental data to support this statement has appeared in print.

Severin ${ }^{(7)}$ published the results of mass inoculation using small numbers of insects. In this work nymphs after feeding singly for 5 minutes on a diseased leaf, were fed 10 minutes on healthy beets with 2 to 7 leaves; 3 nymphs to each leaf, or 6 to 21 to a beet, were used. This experiment was repeated with 12 beet seedlings and 131 nymphs, but not a single case of curly top developed.

A comparison was made of the transmission of curly top by single beet leafhoppers with that by $5,10,20,40$, and 80 specimens, using virus incubation periods varying from 12 to 19 hours and from 19 to 24 hours. In the first experiment from 1 to 40 previously noninfective male leafhoppers were fed on a diseased beet for a period of 11 hours and then hourly on 8 successive healthy beets. In the second experiment from 1 to 80 adults were fed on a diseased beet for a period of 4 hours, then fasted for 14 hours, and fed hourly on 6 successive healthy beets. It was assumed that the virus was not viable on the mouth parts after the insects were kept in cages without focd for a period of 14 hours. The results are indicated in table 4. 
It is evident from table 4 that in these experiments single beet leafhoppers with a virus incubation period varying from 12 to 24 hours failed to transmit curly top when fed 1 hour on each healthy beet; a total of 20 males were fed singly on 140 beets. In all probability, the quantity of virus inoculated into the beets was not sufficient to produce infection. When 5 to 80 leafhoppers were used, the size of the dose of the virus was presumably increased. Infection was produced oftener with 40 to 80 insects than with 5 to 20 . It is evident, however, that 40 to 80 insects failed to transmit the disease every hour after the first infection was obtained.

TABLE 4

Transmission of Curly Top by 1 to 80 Beet Leafhoppers with Virus Incubation Periods of From 12 to 19 and 19 to 24 Hours*

\begin{tabular}{l}
$\begin{array}{c}\text { Virus } \\
\begin{array}{c}\text { incubation period } \\
\text { in insects, } \\
\text { hours }\end{array}\end{array}$ \\
\hline
\end{tabular}

* The plus sign $(+)$ indicates the production of the disease, and the minus sign $(-)$ shows that no disease resulted.

A comparison was made of the transmission of the curly-top virus by two experiments on lots of 1 and of 5 beet leafhoppers which were kept on diseased beets for the same period, and for varying periods on healthy beets on each of 7 successive days. In the first 
experiment previously noninfective males were kept in empty cages for 4 hours, then placed on diseased beets for 7 hours, on Mammoth or Alameda sweet corn, immune to curly top, for 13 hours, and on healthy beet seedlings, for 4 hours during the first day. During the second to the seventh day the insects were kept on sweet corn plants for a period of 20 hours and on healthy beets for 4 hours. In the second experiment the procedure was the same, except that sweet corn plants were not used. The insects were kept on diseased beets for 7 hours and on healthy beets for 17 hours during the first day, and for 24 hours daily on healthy beets during the second to the seventh day. The results are indicated in table 5.

It is evident from table 5 that mass inoculation and the period of exposure of the insects on healthy beets is a factor in the percentage of curly-top transmission. Fifteen previously noninfective males fed singly on 105 beets for a period of 4 hours on 7 successive days transmitted curly top to 8 beets ( 7.6 per cent), whereas 3 lots of 5 males fed for periods of 4 hours on 21 beets on 7 successive days transmitted the disease to 7 beets (33.3 per cent). Fifteen previously noninfective males fed singly on 105 beets for periods of 17 or 24 hours on 7 successive days transmitted curly top to 32 beets ( 30.5 per cent) as compared with 16 diseased beets ( 76.2 per cent) of 21 beets inoculated by 3 groups of 5 males during a 24-hour period.

A comparison was made of the transmission of curly top by 2 lots of $1,2,3,4$, and 5 previously noninfective with infective beet leafhoppers during a period of 1 to 7 days. Previously noninfective males were kept for a period of 7 hours on a diseased beet from which the infective leafhoppers used in this experiment had been removed. They were fed for 17 hours on a healthy beet seedling during the first day and 24 hours daily during the second to the seventh day. The infective insects which had completed the nymphal instars on a diseased beet were transferred daily to successive healthy beets for a period of 7 days. The results are shown in table 6 .

According to table 6,15 previously noninfective beet leafhoppers fed singly on 105 beets during a period of 1 to 7 days transmitted curly top to 33 beets ( 31.4 per cent) whereas 15 infective leafhoppers fed singly on 105 beets during a period of 1 to 7 days transmitted curly top to 65 beets ( 61.9 per cent). Infective insects, which were reared on curly-top beets, probably contain. a larger quantity of the virus than specimens with a virus incubation period of only 1 to 7 days. When 2 previously noninfective and 2 infective insects were used, the average curly-top transmission during a period of 7 days was 66.7 and 81.0 per cent respectively. When 3 previously noninfective and 
3 infective leafhoppers were used, both groups of insects infected 76.2 per cent of the beets. When lots of 4 or 5 leafhoppers were used the average infections obtained by the previously noninfective insects was 71.4 per cent compared with 85.7 per cent with the infective bugs.

TABLE 5

Comparison of Transmission of Curly-Top Virus by Two lots of 1 and 5 Beet Leafhoppers During a Period of 1 to 7 Days, Both Lots Fed on Diseased Beets for 7 Hours

\begin{tabular}{c|c|c|c|c}
\hline $\begin{array}{c}\text { Number of } \\
\text { leafhoppers } \\
\text { on each } \\
\text { beet }\end{array}$ & $\begin{array}{c}\text { Virus } \\
\text { incubation } \\
\text { period in } \\
\text { leafhoppers, } \\
\text { days }\end{array}$ & $\begin{array}{c}\text { Number of } \\
\text { beets } \\
\text { inoculated }\end{array}$ & $\begin{array}{c}\text { Number of } \\
\text { beets } \\
\text { infected }\end{array}$ & $\begin{array}{c}\text { Per cent } \\
\text { infected }\end{array}$ \\
\hline Fed 4 hours daily on a healthy beet during a period of 1 to 7 days \\
\hline 1 & 1 & 15 & 0 & 0.0 \\
1 & 2 & 15 & 3 & 20.0 \\
1 & 3 & 15 & 0 & 0.0 \\
1 & 4 & 15 & 0 & 0.0 \\
1 & 5 & 15 & 2 & 13.3 \\
1 & 6 & 15 & 2 & 13.3 \\
1 & 7 & 15 & 1 & 6.7 \\
\hline Total & $\ldots . . . . . . . .105$ & 8 & 7.6 \\
\hline
\end{tabular}

Fed 17 hours on a healthy beet during the first day and 24 hours daily during the second to the seventh day

\begin{tabular}{r|r|r|r|r}
\hline 1 & 1 & 15 & 3 & 20.0 \\
1 & 2 & 15 & 3 & 20.0 \\
1 & 3 & 15 & 6 & 40.0 \\
1 & 4 & 15 & 7 & 46.7 \\
1 & 5 & 15 & 4 & 26.7 \\
1 & 6 & 15 & 5 & 33.3 \\
1 & 7 & 15 & 4 & 26.7 \\
\hline Total & $\ldots$ & 32 & 30.5 \\
\hline
\end{tabular}

Fed 4 hours daily on a healthy beet during a period of 1 to 7 days

\begin{tabular}{c|r|r|r|r}
\hline 5 & 1 & 3 & 2 & 66.7 \\
5 & 2 & 3 & 2 & 66.7 \\
5 & 3 & 3 & 1 & 33.3 \\
5 & 4 & 3 & 0 & 0.0 \\
5 & 5 & 3 & 1 & 33.3 \\
5 & 6 & 3 & 1 & 33.3 \\
5 & 7 & 3 & 0 & 0.0 \\
\hline Total ........... & $\ldots$ & 21 & 7 & 33.3 \\
\hline
\end{tabular}

Fed 17 hours on a healthy beet during the first day and 24 hours daily during the second to the seventh day

\begin{tabular}{r|r|r|r|r}
\hline 5 & 1 & 3 & 1 & 33.3 \\
5 & 2 & 3 & 2 & 66.7 \\
5 & 3 & 3 & 2 & 66.7 \\
5 & 4 & 3 & 3 & 100.0 \\
5 & 5 & 3 & 3 & 100.0 \\
5 & 6 & 3 & 3 & 100.0 \\
5 & 7 & 3 & 2 & 66.7 \\
\hline Total.......... & $\ldots$ & 21 & 16 & 76.2 \\
\hline
\end{tabular}


TABLE 6

Comparison of Transmission of Curly Top by Two Lots of 1 to 5 Previously Noninfective with Infective Beet Leafhoppers

During a Period of 1 to 7 Days

\begin{tabular}{|c|c|c|c|c|c|c|c|c|}
\hline $\begin{array}{l}\text { Number } \\
\text { of leaf- } \\
\text { hoppers } \\
\text { on each } \\
\text { beet }\end{array}$ & $\begin{array}{c}\text { Virus } \\
\text { incubation } \\
\text { period in } \\
\text { leafhoppers, } \\
\text { days }\end{array}$ & $\begin{array}{l}\text { Number of } \\
\text { beets } \\
\text { inoculated }\end{array}$ & $\begin{array}{l}\text { Number } \\
\text { of beets } \\
\text { infected }\end{array}$ & $\begin{array}{l}\text { Per cent } \\
\text { infected }\end{array}$ & $\begin{array}{c}\text { Number of } \\
\text { leaf- } \\
\text { hoppers } \\
\text { on each } \\
\text { beet }\end{array}$ & $\begin{array}{c}\text { Number of } \\
\text { beets } \\
\text { inoculated }\end{array}$ & $\begin{array}{l}\text { Number } \\
\text { of beets } \\
\text { infected }\end{array}$ & $\begin{array}{l}\text { Per cent } \\
\text { infected }\end{array}$ \\
\hline \multicolumn{5}{|c|}{ Previously noninfective leaf hoppers } & \multicolumn{4}{|c|}{ Infective leafhoppers } \\
\hline 1 & 1 & 15 & 2 & 13.3 & 1 & 15 & 7 & 46.7 \\
\hline 1 & 2 & 15 & 5 & 33.3 & 1 & 15 & 13 & 86.7 \\
\hline 1 & 3 & 15 & 6 & 40.0 & 1 & 15 & 8 & 53.3 \\
\hline 1 & 4 & 15 & 4 & 26.7 & 1 & 15 & 9 & 60.0 \\
\hline 1 & 5 & 15 & 6 & 40.0 & 1 & 15 & 9 & 60.0 \\
\hline 1 & 6 & 15 & 5 & 33.3 & 1 & 15 & 10 & 66.7 \\
\hline 1 & 7 & 15 & 5 & 33.3 & 1 & 15 & 9 & 60.0 \\
\hline Total & $\ldots \ldots \ldots$ & 105 & 33 & 31.4 & $\ldots \ldots \ldots$ & 105 & 65 & 61.9 \\
\hline 2 & 1 & 3 & 1 & 33.3 & 2 & 3 & 1 & 33.3 \\
\hline 2 & 2 & 3 & 2 & 66.7 & 2 & 3 & 2 & 66.7 \\
\hline 2 & 3 & 3 & 2 & 66.7 & 2 & 3 & 3 & 100.0 \\
\hline 2 & 4 & 3 & 2 & 66.7 & 2 & 3 & 3 & 100.0 \\
\hline 2 & 5 & 3 & 2 & 66.7 & 2 & 3 & 3 & 100.0 \\
\hline 2 & 6 & 3 & 3 & 100.0 & 2 & 3 & 2 & 66.7 \\
\hline 2 & 7 & 3 & 2 & 66.7 & 2 & 3 & 3 & 100.0 \\
\hline Total & ......... & 21 & 14 & $\begin{array}{ll}667 \\
\end{array}$ & $\ldots \ldots \ldots$ & 21 & 17 & 81.0 \\
\hline 3 & 1 & 3 & 1 & 33.3 & 3 & 3 & 1 & 33.3 \\
\hline 3 & 2 & 3 & 2 & 66.7 & 3 & 3 & 2 & 66.7 \\
\hline 3 & 3 & 3 & 3 & 100.0 & 3 & 3 & 3 & 100.0 \\
\hline 3 & 4 & 3 & 3 & 100.0 & 3 & 3 & 3 & 100.0 \\
\hline 3 & 5 & 3 & 2 & 66.7 & 3 & 3 & 3 & 100.0 \\
\hline 3 & 6 & 3 & 2 & 66.7 & 3 & 3 & 2 & 66.7 \\
\hline 3 & 7 & 3 & 3 & 100.0 & 3 & 3 & 2 & 66.7 \\
\hline Total & $\ldots$. & 21 & 16 & 76.2 & $\ldots \ldots \ldots$ & 21 & 16 & 76.2 \\
\hline 4 & 1 & 3 & 1 & 33.3 & 4 & 3 & 3 & 100.0 \\
\hline 4 & 2 & 3 & 1 & 33.3 & 4 & 3 & 2 & 66.7 \\
\hline 4 & 3 & 3 & 2 & 66.7 & 4 & 3 & 2 & 66.7 \\
\hline 4 & 4 & 3 & 3 & 100.0 & 4 & 3 & 3 & 100.0 \\
\hline 4 & 5 & 3 & 2 & 66.7 & 4 & 3 & 3 & 100.0 \\
\hline 4 & 6 & 3 & 3 & 100.0 & 4 & 3 & 2 & 66.7 \\
\hline 4 & 7 & 3 & 3 & 100.0 & 4 & 3 & 3 & 100.0 \\
\hline Total & $\ldots \ldots \ldots$ & 21 & 15 & 71.4 & ......... & 21 & 18 & 85.7 \\
\hline 5 & 1 & 3 & 1 & 33.3 & 5 & 3 & 2 & 66.7 \\
\hline 5 & 2 & 3 & 3 & 100.0 & 5 & 3 & 3 & 100.0 \\
\hline 5 & 3 & 3 & 2 & 66.7 & 5 & 3 & 1 & 33.3 \\
\hline 5 & 4 & 3 & 3 & 100.0 & 5 & 3 & 3 & 100.0 \\
\hline 5 & 5 & 3 & 1 & 33.3 & 5 & 3 & 3 & 100.0 \\
\hline 5 & 6 & 3 & 3 & 100.0 & 5 & 3 & 3 & 100.0 \\
\hline 5 & 7 & 3 & 2 & 66.7 & 5 & 3 & 3 & 100.0 \\
\hline Total & $\ldots$ & 21 & 15 & 71.4 & $\ldots \ldots \ldots$ & 21 & 18 & 85.7 \\
\hline
\end{tabular}




\section{INCUBATION PERIOD OF VIRUS IN BEET LEAFHOPPER}

The virus incubation period in the beet leafhopper should be defined as the time for the infective principle to pass into the mouth parts, alimentary canal, blood, and salivary glands and out of the mouth parts in sufficient quantity to produce infection. The term incubation period should not be used when testing short periods of the transmission of the disease, such as contamination of mouth parts.

Carsner and Stahl ${ }^{(2)}$ demonstrated that a single insect was able to transmit curly top within a period of $213 / 4$ hours. These investigators reported "that a greater number of insects become able to transmit the virus after a longer period than 24 hours than are able to do so in the shorter time. The facts cited seem to indicate that a multiplication of the causal agent takes place within the insects."

The virus incubation period in single previously noninfective insects is given in table 6 . The percentage of curly top obtained with single insects varied from 13.3 to 40.0 during virus incubation periods of 1 to 7 days, the lowest percentage occurring at the end of 1 day.

\section{CONTAMINATION OF MOUTH PARTS}

An experiment was conducted in which the mouth parts from beet leafhoppers were cut off in a culture medium and fed to noninfective leafhoppers. The mouth parts from 1,000 adults were dissected, 100 being used in each experiment. Previously noninfective adults, after being kept in an empty cage for a period of 6 hours, began to feed on a diseased beet within a few minutes under high temperatures in the greenhouse. After successive lots of 25 insects had fed for periods of $1 / 2$ to 1 hour, they were captured with a pipette, etherized, and dissected. The labium, maxillae, and mandibles were cut off with a small triangular scalpel on clean slides and put into equal volumes of steam-extracted beet-root juice and sterile distilled water containing 5 per cent beet sugar. The mouth parts in the culture medium were ground in a mortar and fed to noninfective nymphs.

Feeding equipment was devised in which a small quantity of culture medium was employed. Microculture slides were used in which the depression containing the culture medium was $18 \mathrm{~mm}$ in diameter and $3 \mathrm{~mm}$ deep. Specimen vials $(90 \times 24 \mathrm{~mm})$ were cut about an inch below the constriction by nichrome wire heated with elec- 
tricity The cut surface below the neck of the vial was flared and covered with fish skin which was held in place by elastic bands below the flare. The nymphs were placed in the cut vial with a pipette, and the mouth was covered with silk bolting. The membrane was now put in contact with the culture medium containing the mouth parts (fig. $4)$. The feeding equipment was placed on a plate of glass below a bell jar, with a beaker of water to prevent evaporation (fig. 5).

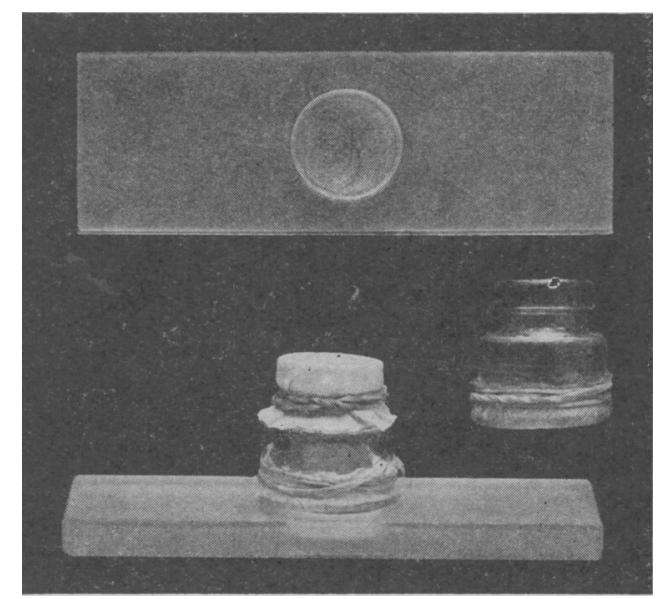

Fig. 4. Equipment used in feeding noninfective nymphs on culture media containing feces or severed mouth parts from infective beet leafhoppers. A ' fishskin' membrane, covering the flared surface of the glass cage, was in contact with the culture media containing the feces or severed mouth parts in the depression of a microculture slide. The opened end of the cage containing the nymphs was covered with silk bolting.

Noninfective nymphs after feeding on the culture medium containing the mouth parts were transferred to 30 beet seedlings, using about 20 hoppers for each beet. Two typical cases of curly top developed, but the incubation periods of the disease in the beets were 24 and 34 days, respectively. The asual period for symptoms to develop in beet seedlings with 6 to 8 leaves is from 1 to 2 weeks during the summer.

After the mouth parts were dissected in each experiment, the heads, containing the blood and salivary glands, were placed in a culture medium and ground in a mortar. The culture medium containing the crushed heads was centrifuged for about an hour, and either fed directly to noninfective nymphs or after filtering through coarse and fine Berkefeld candles. Noninfective nymphs, after feeding on the filtered and unfiltered culture media, in which the heads without 
mouth parts were crushed, failed to transmit curly top to healthy beet seedlings. It appears from this experiment that in feeding noninfective beet leafhoppers on curly top beets for a period of $1 / 2$ to 1 hour, the virus failed to pass through the wall of the midintestine into the blood and salivary glands.

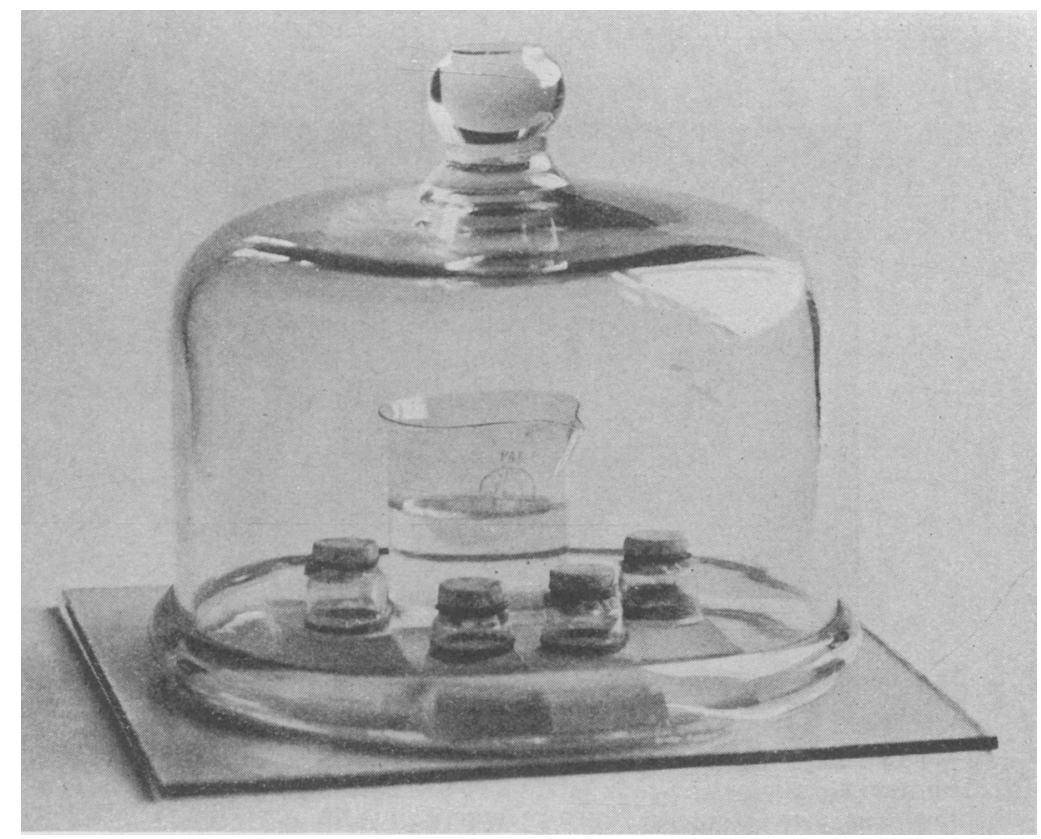

Fig. 5. The feeding equipment and a beaker of water under a bell jar resting on a glass plate, to prevent evaporation of the culture media containing the feces or severed mouth parts.

\section{FECES}

A common method of insect transmission of diseases to plants is through the feces containing spores of fungi or bacteria. "Among fungus diseases, the spores of at least seven parasitic species have been shown capable of passing through the intestinal canal in a viable condition." ${ }_{(6)}$ Infection with bacterial wilt of cucurbits takes place directly from the feces of the striped and twelve-spotted cucumber beetle (Diabrotica vittata, and D. duodecimpunctata) brought in contact with a leaf injured by the feeding beetles. Among human and animal diseases it has been shown that the feces of infected fleas when applied to the abrasion in the skin produces bubonic plague, and in a similar manner the feces of infected lice produce typhus fever. 
Severin ${ }^{(8)}$ failed to transmit curly top by inoculating the feces from infective beet leafhoppers into the petioles of healthy beets.

Carsner and Stahl ${ }^{(2)}$ dipped the point of a steel needle into drops of fresh excreta from the leafhopper and then pricked the excrement into two beet seedlings; no disease resulted.

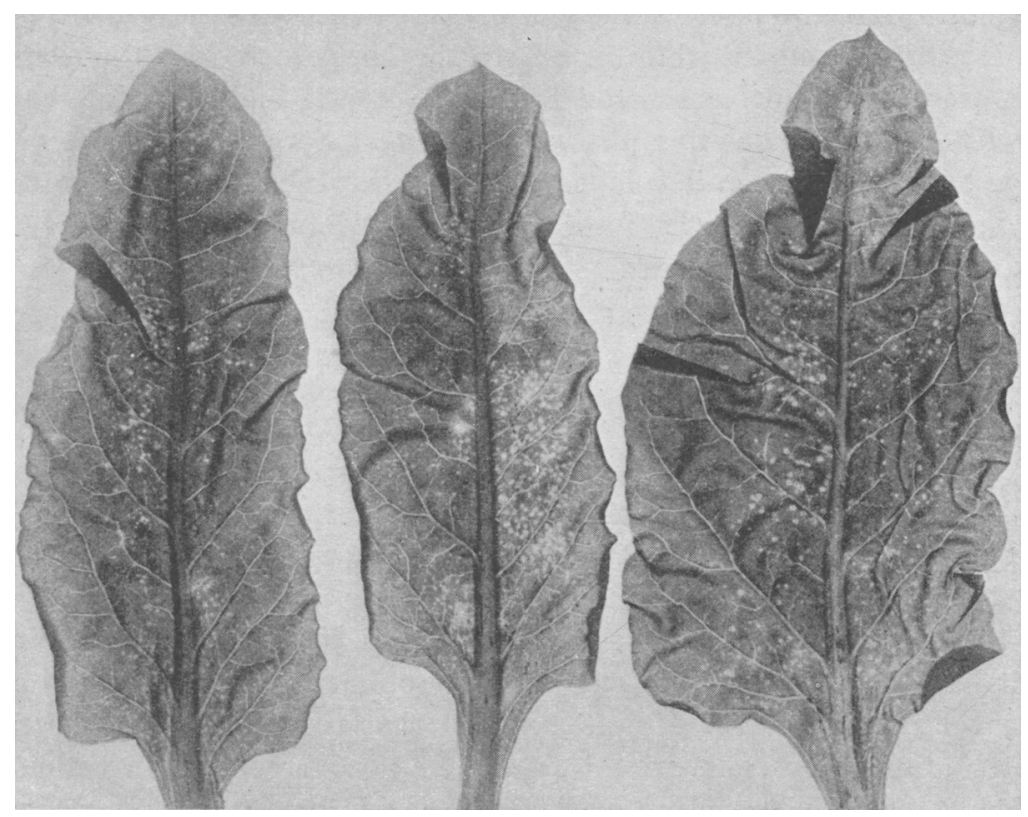

Fig. 6. Mouth-part punctures of beet leafhoppers in blades of sugar beets. The puncture is in the center of the white circular area. Mouth-part punctures are rarely visible to the naked eye, but when large numbers of adults feed on the thin younger leaves, an occasional leaf may show the white circular areas.

When large numbers of beet leafhoppers are reared on beets, mouth-part punctures are common in the foliage, as may be seen by examining it with a binocular miscroseope. Mouth-part punctures are rarely visible to the naked eye but when large numbers of adults feed on the thin younger leaves, an occasional leaf may show white circular areas with the puncture in the center (fig. 6). If some of the curlytop virus passes through the digestive canal of the hopper in a viable condition, and the excreta is spurted into the feeding punctures, the virus might possibly thus enter the phloem of the beet leaves.

Since juice pressed from the leaves and roots of curly-top beets, when inoculated into the crown of healthy beets, produced such a low percentage of infection, ${ }^{(10)}$ it was decided to feed noninfective beet 
leafhoppers on the feces of infective hoppers, by the methods described by Carter ${ }^{(4,5)}$ and Severin and Swezy. ${ }^{(12)}$

During the past two years about 12,000 infective beet leafhoppers were confined at the rate of about 500 adults to each sterile test tube for periods varying from 10 to 60 minutes; the feces were then washed from the test tubes with various culture media. In some experiments the culture medium containing the excrement was fed directly to noninfective nymphs, while in others the hoppers fed on the filtrate prepared from the feces while fresh or after it had been incubated for 1 to 6 weeks. The nymphs were then transferred to 91 beet seedlings but no curly top developed. Further experiments are necessary to determine whether the feces from infective beet leafhoppers are toxic to the curly-top virus.

\section{DISCUSSION}

Regurgitation of food is common among insects. Insects sometimes vomit after overfeeding or after taking in poisoned food. It has been demonstrated that disease-producing microorganisms which have been taken up by insects were in an infective state in the vomit spots.

Swezy ${ }^{(14)}$ found only 1 beet leafhopper in 250 specimens examined that had two lumps of bacteria in the esophagus anterior to the esophageal valve (fig. 1). It was assumed that this abnormal condition of the alimentary canal would explain the occurrence of infection in $1 / 2$ to 1 hour. There is no evidence to show, however, that a single previously noninfective beet leafhopper after feeding on a diseased beet can transmit curly top in these short periods.

If an obstruction in front of the esophageal valve occurs in the beet leafhopper, or if the hopper gorges the midintestine with food in overfeeding under high temperatures, so that the esophagus becomes greatly distended, then after the withdrawal of the mouth parts, some of the beet juice should flow from the foreintestine through the canal in the setae and accumulate as a droplet at the end of the labium. A droplet of beet juice at the end of the beak has never been observed with the work on short periods of curly-top transmission and other feeding experiments. Droplets of excrement are plainly visible to the naked eye, but in hundreds of experiments extending over a period of thirteen years, a leafhopper with a drop of beet juice at the end of the labium has never been observed.

If a beet leafhopper is vivisected and the contractions of the alimentary canal are studied, the movement of the esophageal valve is 
always a swallowing movement as has been described in other insects. A peristaltic movement of the foreintestine aided by a swallowing movement of the esophageal valve, should force a plastic mass of bacteria through the valve into the midintestine. The esophageal valve, however, prevents regurgitation from the midintestine into the foreintestine.

Two other theories were proposed by Swezy ${ }^{(14)}$ to account for the short periods of curly-top transmission by the beet leafhopper (1) by the passage of the infective organism unchanged through the body of the insect, and (2) by a change and completion of a life cycle of an infective organism.

It has not been proved, however, that the curly-top virus can pass through the body of the leafhopper quickly enough to account for curly-top transmission in short periods. In the experiments reported in this paper, the curly-top virus was not obtained from filtrates prepared from crushed heads of the leafhoppers with the mouth parts removed, when the insects had fed only $1 / 2$ to 1 hour on curly-top beets. Curly-top transmission was obtained, however, with the cultures prepared from mouth parts of large numbers of insects which had fed on curly-top beets for only $1 / 2$ to 1 hour.

These experiments indicate that contamination of mouth parts, without multiplication of the curly-top virus in the body of the insect may account for the transmission of the disease in short intervals.

Curly-top transmission in short intervals by single insects feeding on diseased beets and then on healthy beets has not been accomplished up to the present time. The quantity of virus washed by the saliva from the mouth parts of large numbers of leafhoppers into the feeding punctures is probably a factor in the transmission of the disease. When juice is extracted from the blades and petioles of curly-top beets, a rapid inactivation of the virus occurs, but whether this is the case with the virus on the mouth parts when withdrawn from the phloem is not known. The season of the year and temperature are factors in the short periods of curly-top transmission by the beet leafhopper.

\section{SUMMARY}

If an experiment on short periods of transmission, 40 previously noninfective beet leafhoppers after feeding on a diseased beet transmitted curly top to a healthy beet within 20 minutes. The percentage of curly-top transmission varied with the time that the healthy beet was exposed to infection as follows: 20 minutes, 2.4 per cent; $1 / 2$ hour, 
14.3 per cent; 1 hour, 2.9 per cent; $11 / 2$ hours, 16.7 per cent; 2 hours, 15 per cent; 3 hours, 27.8 per cent; and 4 hours, 33.3 per cent. When 20 to 50 adults were used, the transmission of the disease within 20 minutes to 4 hours averaged 7.3 per cent with 96 beets, as compared with 22.5 per cent with 129 beets when more than 50 hoppers were used. Curly top was not transmitted when 5 to 15 insects were used in short feeding intervals.

A number of experiments were performed varying the time of exposure of single previously noninfective beet leafhoppers on diseased and healthy beets with the following results: a total of 203 leafhoppers, after feeding singly on diseased and healthy beet seedlings for periods varying from 2 to 11 hours, transmitted curly top to only 4 (2.0 per cent) of 203 beets. The shortest period for a single insect to transmit curly top was 7 hours. Fifty leafhoppers with a virus incubation period of from 13 to 23 hours, tested singly, transmitted curly top to 9 ( 3 per cent) of 300 beets. In another experiment 20 males with a virus incubation period of from 12 to 24 hours, fed singly on 140 beets, failed to transmit curly top.

When lots of $5,10,20,40$, or 80 leafhoppers fed hourly on different healthy beets, the size of the dose of the virus was increased; infection was produced oftener with 40 or 80 insects than with 5,10 , or 20 hoppers.

The relation of mass inoculation by groups of beet leafhoppers to curly-top transmission was demonstrated by varying the time of exposure of the insects on healthy beets. Fifteen previously noninfective males fed singly on 105 beets for a period of 4 hours on 7 successive days transmitted curly top to 8 beets ( 7.6 per cent) whereas 3 lots of 5 males fed for periods of 4 hours on 21 beets on 7 successive days transmitted the disease to 7 beets (33.3 per cent). Fifteen previously noninfective males fed singly on 105 beets for periods of 17 or 24 hours on 7 successive days transmitted curly top to 32 beets ( 30.5 per cent) compared with 16 diseased beets ( 76.2 per cent) by 3 groups of 5 males during a 24 -hour period.

The percentage of curly top transmitted by single insects with virus incubation periods of 1 to 7 days varied from 13.3 to 40 per cent, the lowest percentage occuring at the end of 1 day. The exposure of each male on a diseased beet was 7 hours, and on each healthy beet 17 hours during the first day and 24 hours during each of the next 6 days.

The mouth parts were contaminated with the curly-top virus after the leafhoppers had fed on a diseased beet for periods of $1 / 2$ to 1 hour. 
The mouth parts were cut off, put in a culture medium, and ground in a mortar. Previously noninfective nymphs after feeding on the culture medium transmitted curly top to 2 beet seedlings but the incubation period of the disease in the beet was prolonged, requiring 24 and 34 days, respectively.

Noninfective nymphs after feeding on culture media containing the excreta or on the filtrate prepared from the feces failed to transmit curly top to healthy beets.

\section{LITERATURE CITED}

1 Bacot, A. W., and C. J. Martin.

1914. Observations on the mechanism of the transmission of plague of fleas. Jour. Hygiene, Plague Suppl. 3:423-439.

2 Carsner, E., and C. F. Stahl.

1924. Studies on curly-top disease of the sugar beet. Jour. Agr. Res. $28: 297-319$.

3 CARSNer, E., and C. F. LACKer.

1929. Mass action in relation to infection with special reference to curly top of the sugar beet. Phytopath. 19:1137.

4 CARTER, W.

1927. A technique for use with homopterous vectors of plant diseases, with special reference to the sugar-beet leafhopper, Eutettix tenellus

5 CARter, W. (Baker). Jour. Agr. Res. 34:449-451.

1928. An improvement in the technique for feeding homopterous insects. Phytopath. 18:246-247.

6 RAND, F. V., and W. D. Pierce.

1920. A coordination of our knowledge of insect transmission in plant and animal diseases. Phytopath. 10:189-231.

7 SEVERIN, H. H. P.

1921. Minimum incubation periods of causative agent of curly leaf in beet leafhopper and sugar beet. Phytopath. 11:424-429.

8 Severin, H. H. P.

1922. Curly-top transmission experiments. Jour. Econ. Entom. 15:182.

9 Severin, H. H. P.

1923. Incubation period. California Agr. Exp. Sta. Rept. 1922-23:127.

10 SEVERIN, H. H. P.

1924. Curly-leaf transmission experiments. Phytopath. 14:80 -93 .

11 Severin, H. H. P.

1924. California Agr. Exp. Sta. Rept. 1923-24:42. 
12 Severin, H. H. P., and O. SwezY.

1928. Filtration experiments of curly top of sugar beets. Phytopath. 18:681-690.

13 Smith, R. E., and P. A. Boncquet.

1915. Connection of a bacterial organism with eurly leaf of the sugar beet. Phytopath. 5:335-342.

14 SWEzY, O.

1930. Factors influencing the minimum incubation periods of curly top in the beet leafhopper. Phytopath. 20:93-100. 